\title{
Sprækker i revolutionen
}

En hvisken i øret under Udenrigspolitisk Selskabs studierejse til Iran blev uventet et varsel om den senere tumultariske afvikling af præsidentvalget den 12. juni.

Den diskrete hvisken skete under besøget i Hensigtsmæssighedens Råd, hvor analytikere anbefalede os at holde øje med reformkandidaten Mousavi. Hvorfor, fik vi ikke at vide. Var det en prognose for vælgernes ønske? Eller ville formanden for hensigtsmæssighedens Råd, Hashemi Rafsanjani, helst have det sådan, at Mousavi skulle vinde?

Dengang aftalte vi Iran-artiklerne til denne udgave af Udenrigs - før valget og før de voldsomme uroligheder, som fulgte.

$\mathrm{Nu}$, hvor Udenrigs går i trykken, ved vi ikke, hvor urolighederne fører hen. Men vi ved, at en ung smuk kvinde, Neda, netop er blevet skudt og dræbt af bøllekorpset 'Basij' for rullende kameraer, under omfattende folkelige protester mod klar regeringsmanipulation med valgresultatet.

Neda er hurtigt blevet protesternes ikon. Vogterne Råd har medgivet, at der i 50 valgkredse synes afgivet flere stemmer, end der er registrerede vælgere. Men den hidtidige præsident, Ahmadinejad, er erklæret officiel vinder, og reformkandidaten Mousavi råber 'snyd' og kræver valget omgjort.
Og nu ved vi, at Rafsanjani - én af Irans mest magtfulde mænd - vitterligt havde ønsket, at Mousavi skulle vinde posten som Irans præsident. Derfor ved vi også, at flere af de kendte deltagere i det ellers ganske anonyme magtspil i Iran var splittede ved valget.

Vi ved i hvert fald, at den øverste åndelige vejleder, ayatollah Khamenei, og det indflydelsesrige Vogternes Råd satsede på at give Ahmadinejad valgsejren. Vi ved også, at Rafsanjani - som leder af både Hensigtsmæssighedens Råd, som tager centrale politiske beslutninger, hvis parlamentet og Vogternes Råd er uenige, og Eksperternes Råd, som ene af alle skal udpege den ny åndelige vejleder efter Khamanei - satsede på reformkandidaten Mousavi. Vi ved, at Revolutionsgarden synes at bakke Ahmadinajad op - men vi ved ikke, hvor hæren og politiet har deres loyalitet.

Til gengæld ved vi, at den øverste skriftlærde i hele Iran, storayatollah Montazeri, fra sin husarrest i den hellige by Qom, kaldte det uofficielle valgresultat utroværdigt og reelt sagde god for mytteri i politiet ved at minde betjente om, at de ikke kan deltage i nedkæmpning af folkelige protester med henvisning til, at de har fået ordrer dertil. Det vil ikke være en undskyldning over for Gud, meddelte Montazeri. 
Med andre ord: Den islamiske revolution har oplevet sine hidtil største sprækker indadtil. De religiøse magthavere er blevet skarpt kritiseret af den højeste muslimske sagkundskab - og mødt af de hidtil stærkeste folkelige protester.

Hvordan skal det internationale samfund herefter forholde sig til de iranske magthavere - der er svækket politisk, men næppe mindre opsat på at gennemføre deres atomprojekt? Og hvad er det for et Iran, der i juni viste tegn på at krakelere indefra? En voldsom forsommer. En dramatisk udvikling.

Vi ved som sagt ikke, hvor det ender, men læs fx Vibeke Sperlings reportage fra kulturrevolutionen $\mathrm{i}$ Teherans gader, Herbert Pundiks beretning om splittelsen i Irans ledende eliter, Anders Jerichows analyse af Irans atompolitik og Ditlev Tamms samtale om lov og ret i Iran. Som altid indeholder Udenrigs an- det og mere end sin tema: Kristian Søby Kristensen giver et bud på, om Anders Fogh Rasmussens nye job mest bliver som general eller sekretær, og professor i økonomi Claus Vastrup analyserer tilbundsgående de økonomiske konsekvenser af $\varnothing \mathrm{MU}$ 'en. Desuden skriver fuldmægtig under Forsvarsministeriet Adam Beresowski om forholdet RuslandUSA; kontorchef Lars Bo Møller og fuldmægtig Rasmus Abildgaard Kristensen, begge Udenrigsministeriet, gennemgår ministeriets ny struktur; ph.d.-studerende Lizaveta Dubinka analyserer danmarkiseringen af Hvideruslands udenrigspolitik; og Herbert Pundiks redegør for, hvordan den jødiske og den palæstinensiske selvstændighedsbevægelse har udviklet sig ad parallelle spor.

God læselyst!

\section{Redaktionen}

